\title{
Pemodelan Faktor - Faktor Pemilihan On-Street Parking di Kawasan Tunjungan dan Blauran Kota Surabaya
}

\author{
Laura Andretha dan Ketut Dewi Martha Erli Handayeni \\ Departemen Perencanaan Wilayah dan Kota, Fakultas Arsitektur, Desain, dan Perencanaan, \\ Institut Teknologi Sepuluh Nopember (ITS) \\ e-mail: erli.martha@urplan.its.ac.id
}

\begin{abstract}
Abstrak-Kawasan Tunjungan dan Kawasan Blauran adalah kawasan - kawasan yang merupakan titik pusat kegiatan di Kota Surabaya dan juga memiliki parkir tepi jalan. Kedua kawasan ini mempunyai keadaan lalu lintas yang padat dengan derajat kejenuhan jalan - jalan di kawasan tersebut dalalm kategori tidak stabil serta merupakan kawasan yang termasuk dalam peraturan parkir zona dengan tarif lebih tinggi. Maka, implementasi kebijakan parkir yang telah ditetapkan tersebut diharapkan dapat mengurangi penggunaan kendaraan pribadi ke pusat kota. Dalam praktiknya di berbagai kota, kebijakan parkir akan memberikan pengaruh terhadap perilaku parkir. Oleh karena itu penelitian ini bertujuan untuk menyusun model dan mengetahui bagaimana faktor - faktor yang memengaruhi pemilihan on-street parking. Metode yang digunakan dalam mengembangkan model adalah analisa regresi logistik biner. Hasil dari studi menunjukkan bahwa variabel yang memengaruhi pemilihan on-street parking pada pengguna parkir kendaraan bermotor roda dua adalah pendapatan, durasi parkir, dan biaya parkir. Kemudian, pada pengguna parkir kendaraan bermotor roda empat, variabel - variabel yang memengaruhi pemilihan onstreet parking adalah usia, maksud perjalanan, durasi parkir, dan jarak berjalan kaki.
\end{abstract}

Kata Kunci-On-Street Parking, Stated Preference, Regresi Logistik Bine.r

\section{PENDAHULUAN}

$\mathrm{P}$ ERTUMBUHAN jumlah kendaraan pribadi berpotensi menimbulkan masalah dalam penataan parkir. Limpahan parkir kendaraan bermotor terjadi bukan saja di dalam gedung atau ruang parkir, melainkan juga sampai ke badan jalan perkotaan. Limpahan parkir ini mengakibatkan gangguan berupa tertundanya arus lalu lintas [1].

Keberadaan titik - titik parkir tepi jalan di pusat kegiatan Kota Surabaya menimbulkan kepadatan lalu lintas karena badan jalan yang terpakai untuk parkir jalan. Hal ini memicu kecepatan arus menjadi rendah yang merupakan gejala awal kemacetan lalu lintas. Kawasan Tunjungan dan Blauran merupakan kawasan - kawasan pusat kegiatan di Kota Surabaya yang memiliki parkir tepi jalan. Kedua kawasan ini mempunyai keadaan lalu lintas yang padat. Rata - rata derajat kejenuhan jalan (DS) di Kawasan Tunjungan berada di angka 0.9 dan Kawasan Blauran sendiri di angka 0.85 [2]. Berdasarkan MKJI, jalan dengan derajat kejenuhan antara 0,8 - 1 adalah jalan yang berada dalam kondisi tidak stabil. Dalam
RTRW Kota Surabaya 2013, kedua kawasan ini juga termasuk dalam titik - titik parkir tepi jalan yang menjadi perhatian.

Data Dinas Perhubungan Kota Surabaya tahun 2017 menunjukkan tepi jalan Kawasan Tunjungan rata - rata perharinya berpotensi menjadi lahan parkir bagi 1263 mobil dan 314 motor, sedangkan di sisi tepi jalan Kawasan Blauran per harinya berpotensi dipakai sebagai tempat parkir untuk 856 mobil dan 2561 motor. Sebagian besar dimensi parkir kedua kawasan tersebut berbentuk parkir paralel [2]. Potensi ruang parkir yang besar ini mengundang mobil datang dan membangkitkan pergerakan mobil [3]. Selain itu, lebar jalan yang tersita oleh kegiatan perparkiran mengurangi kemampuan jalan dalam kinerjanya [4].

Dengan tingginya tingkat potensi parkir di kawasan kawasan tersebut, Dinas Perhubungan Kota Surabaya menerapkan kebijakan parkir zona berdasarkan [5], [2] untuk memengaruhi lalu lintas dan kemacetan Kota Surabaya yang disebabkan oleh parkir. Penerapan kebijakan ini berfokus pada peningkatan tarif/ harga parkir dan merupakan instrumen penataan parkir tepi jalan umum untuk mengurangi kemacetan di Kawasan Tunjungan dan Blauran, bersamaan dengan 12 kawasan lainnya.

Penetapan kebijakan biaya parkir merupakan salah satu jenis upaya travel demand management (TDM). Dalam perumusan kebijakan parkir, yang menjadi pertimbangan pertama adalah perilaku atau pilihan konsumennya [6]. Perilaku masyarakat terhadap kebijakan parkir juga memberikan dampak pada efektivitas dari kebijakan itu sendiri. Perilaku parkir merupakan setiap sikap dan pola perilaku pengguna yang berkaitan dengan parkir [7]. Namun, kurangnya informasi mengenai perilaku parkir masyarakat, mempersulit untuk menetapkan kebijakan parkir yang efektif [8]. Untuk memahami bagaimana orang membuat keputusan parkir, haruslah dipertimbangkan berbagai faktor, dan harga parkir hanyalah salah satunya [9]. Oleh karena itu, diperlukan kajian untuk mengetahui faktor - faktor yang memengaruhi pemilihan parkir tepi jalan di Kawasan Tunjungan dan Blauran Kota Surabaya guna menjadi pengembangan kebijakan parkir dan mengatasi kemacetan. 


\section{METODE PENELITIAN}

\section{A. Variabel Penelitian}

Variabel yang digunakan untuk mengidentifikasi karakteristik pelaku parkir antara lain adalah jenis kelamin, umur, pendapatan, dan kepemilikan kendaraan. Kemudian variabel penelitian yang dipakai untuk mengidentifkasi karakteristik perjalanan pelaku parkir terdiri dari tujuan perjalanan, jumlah tujuan perjalanan, serta waktu/ lama perjalanan.

Variabel penelitian yang digunakan untuk mengidentifikasi karakteristik perparkiran adalah durasi parkir, biaya/ tarif parkir, jarak berjalan kaki, kemudahan fasilitas parkir, dan keamanan fasilitas parkir

\section{B. Populasi dan Sampel}

Populasi dari penelitian ini adalah para pelaku parkir di delapan ruas jalan yang termasuk dalam parkir zona di Kawasan Tunjungan dan Kawasan Blauran, Kota Surabaya. Teknik sampling yang digunakan pada penelitian ini adalah teknik simple random sampling yang dimaksudkan agar pengambilan sampel dilakukan secara acak (random), sehingga setiap elemen dalam populasi memiliki kesempatan yang sama besar untuk terpilih sebagai sampel penelitian. Jumlah sampel yang dibutuhkan untuk mewakili populasi dihitung dengan rumus Slovin [10] yang menggunakan margin error sebesar $10 \%$ atau 0,1 .

Populasi yang digunakan dalam penelitian ini adalah jumlah pengguna on-street parking di Kawasan Tunjungan dan Blauran yang terbagi antara 2119 pengguna mobil dan 2875 sepeda motor. Maka sampel yang dapat adalah sebagai berikut:

$$
\begin{aligned}
& \text { Mobil }(\mathrm{R} 4) \\
& n=\frac{2119}{1+2119(0.1)^{2}} \\
& =\frac{2119}{1+21.19} \\
& =95.49
\end{aligned}
$$

$$
\begin{aligned}
& \text { Sepeda Motor (R2) } \\
& \begin{aligned}
n= & \frac{2875}{1+2875(0.1)^{2}} \\
& =\frac{2875}{1+28.75} \\
& =96.63
\end{aligned}
\end{aligned}
$$

\section{Metode Analisis}

Tahapan pertama yang dilakukan dalam penelitian ini adalah mengidentifikasi karaktersiti pelaku parkir dan perilaku perjalanannya di wilayah studi. Kemudian dalam tahap kedua adalah mengidentifikasi karakteristik on-street parking yang termasuk dalam wilayah studi. Kedua tahapan ini akan di proses menggunakan analisa statistik deskriptif. Demi mendapatkan data masukan untuk analisis sasaran ini, dilakukan penyebaran kuesioner kepada para responden yang menjadi pengguna fasilitas on-street parking di wilayah penelitian.

Kemudian dalam tahap terakhir dilakukan analisis faktor faktor yang memengaruhi pemilihan on-street parking. Metode yang digunakan adalah model logit binomial atau dapat disebut juga regresi logistik biner yang mempunyai bentuk umum sebagai berikut [4]:

$$
Y=\ln \left[\frac{p}{1-p}\right]=\beta_{0}+\beta_{1} X_{1}+\beta_{2} X_{2}+\cdots+\beta_{n} X_{n}
$$

$$
p=\frac{1}{1+e^{-\left(\beta_{1} X_{1}+\cdots+\beta_{n} X_{n}\right)}}
$$

Dimana:

$$
\begin{aligned}
& \text { ln : Logaritma natural } \\
& \text { : Peluang pemilihan on-street parking di dalam } \\
& \text { p } \quad \text { zona (park) } \\
& 1-p \quad \text { : Peluang pemilihan tidak parkir di dalam zona (not } \\
& \text { park) } \\
& \beta_{0} \quad: \text { Konstanta } \\
& \beta_{n} \quad: \text { Koefisien variebel X ke } \mathrm{n} \\
& X_{n} \quad \text { : Variabel indpenden / prediktor ke } \mathrm{n} \\
& e \quad \text { : Bilangan napier }
\end{aligned}
$$

Adapun variabel - variabel yang dijadikan variabel independen untuk mengetahui faktor - faktor yang berpengaruh dalam pemilihan on-street parking adalah variabel yang diindentifikasi dari karakteristik pada sasaran sebelumnya. Karena penelitian ini membahas mengenai faktor pemilihan on-street parking dan hal tersebut berkaitan erat dengan perilaku pemilihan. Perilaku pemilihan dapat diprediksi dengan menggunakan metode pendekatan stated preference (SP) [11]. SP melibatkan desain hipotesa dengan manipulasi level atribut yang direncanakan untuk menghasilkan output yang relevan secara statistik. Maka untuk hipotesanya digunakan atribut atau variabel biaya parkir dan durasi parkir yang akan didesain kedalam masing - masing tiga level. Analisis ini dilakukan dengan bantuan software IBM SPSS Statistics 24.

\section{HASIL DAN DISKUSI}

A. Identifikasi Karakteristik Pelaku Parkir dan Perilaku Perjalanannya di Kawasan Tunjungan dan Blauran Kota
1.) Karakteristik Pelaku Parkir
a. Jenis Kelamin

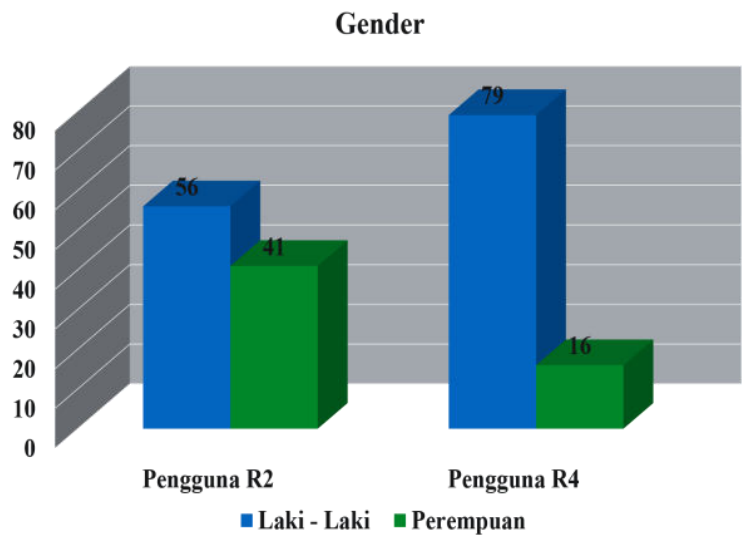

Gambar 1 Jumlah Pengguna Parkir Berdasarkan Gender.

Di variabel gender baik pengguna on-street parking untuk kendaraan R2 maupun R4 sama - sama lebih di dominasi oleh pengguna dengan gender laki - laki. Untuk kendaraan R2 sebesar $58 \%$ pengguna on-street parkingnya adalah laki - laki, sedangkan untuk kendaraan R4 ada sebesar 83\% dari keseluruhan responden. 
b. Tingkat Pendapatan

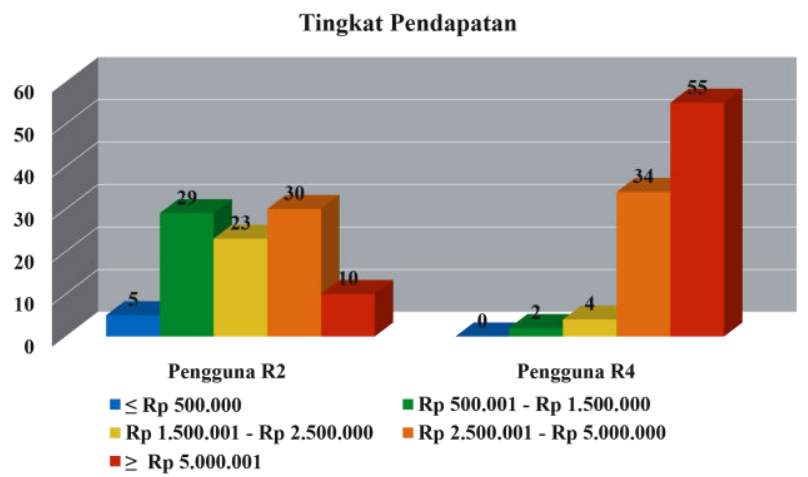

Gambar 2 Jumlah Pengguna Parkir Berdasarkan Tingkat Pendapatan.

Dalam variabel tingkat pendapatan, untuk pengguna onstreet parking kendaraan R2-nya didominasi sebesar 31\% oleh pengguna dengan tingkat pendapatan antara Rp $2.500 .000-$ Rp 5.000.000, sedangkan untuk R4 paling banyak pengguna yang mempunyai tingkat pendapatan $\geq R$ p 5.000.000, yaitu sebanyak 58\% dari responden R4. Pengguna on-street parking kendaraan R4 mempunyai tingkat pendapatan yang lebih tinggi dari pada pengguna on-street parking kendaraan R2.

$$
\text { c. Usia }
$$

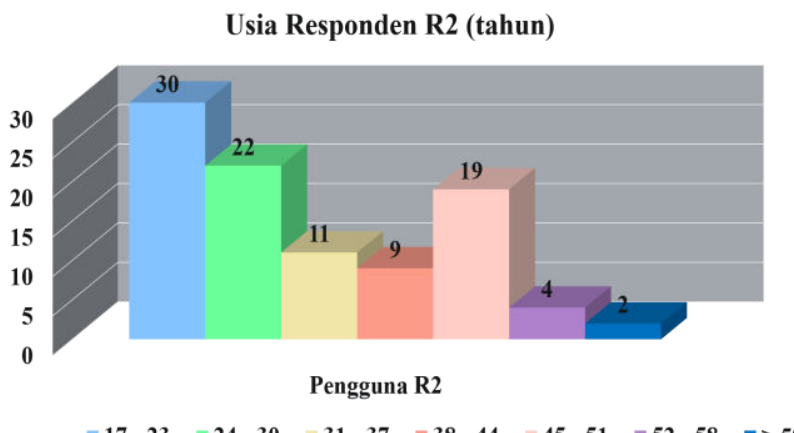

Gambar 3. Jumlah Pengguna Parkir R2 Berdasarkan Usia.

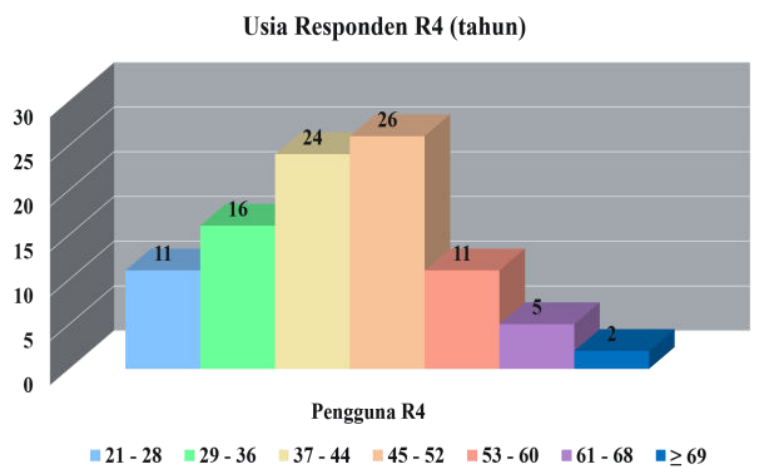

Gambar 4. Jumlah Pengguna Parkir R4 Berdasarkan Usia.

Pada variabel usia, pengguna parkir untuk kendaraan R2 didominasi oleh kelompok usia antara $17-23$ tahun yakni sebesar $31 \%$, sedangkan untuk pengguna parkir kendaraan R4 didominasi oleh kelompok usia antara 45 - 52 tahun, yakni sebesar $27 \%$ dari keseluruhan respondennya. Maka, baik pengguna on-street parking kendaraan R2 maupun R4 sama sama didominasi oleh pengguna dalam kelompok usia produktif.

\section{d. Jumlah Kepemilikan Kendaraan}

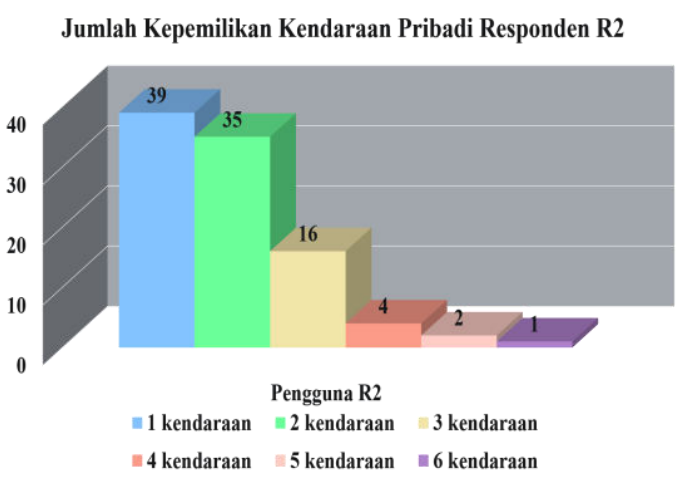

Gambar 5 Jumlah Pengguna Parkir R2 Berdasarkan Kepemilikan Kendaraan.

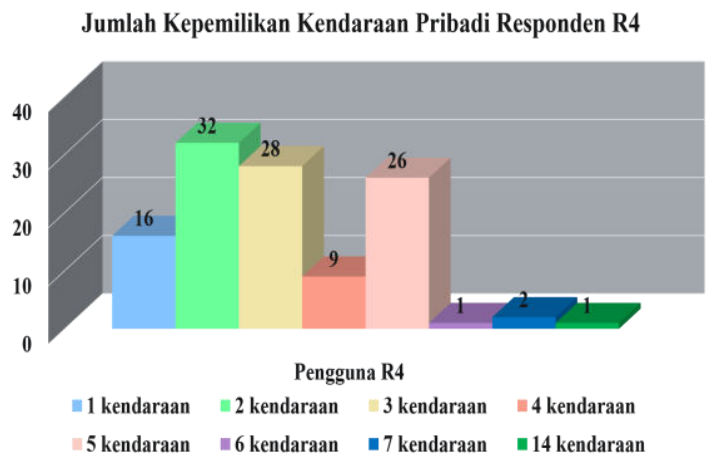

Gambar 6. Jumlah Pengguna Parkir R4 Berdasarkan Kepemilikan Kendaraan.

Pengguna on-street parking untuk kendaraan R2 paling banyak yang mempunyai satu kendaraan pribadi $(40 \%$ responden R2), sedangkan untuk pengguna kendaraan R4 didominasi (34\% responden $\mathrm{R} 4$ ) oleh responden mempunyai kendaraan pribadi sebanyak dua buah.

2.) Karaktersitik Perilaku Perjalanan

a. Maksud/ Tujuan Perjalanan

b.

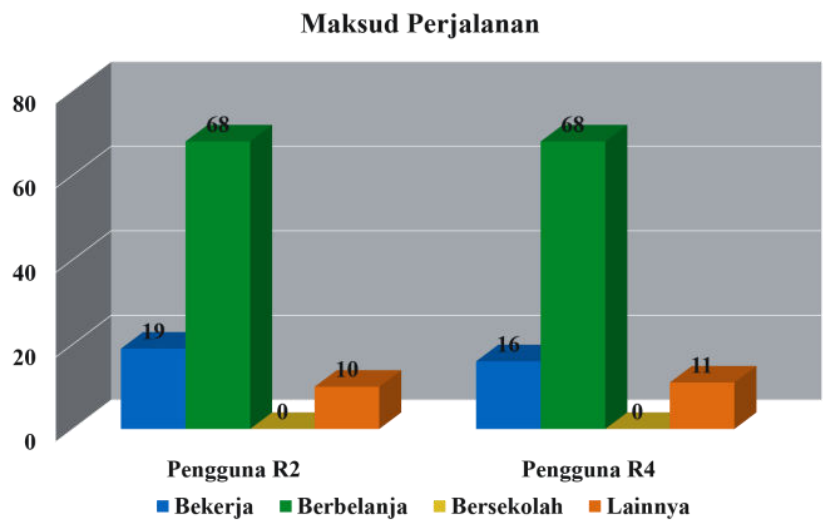

Gambar 7 Jumlah Pengguna Parkir Berdasarkan Maksud Perjalanan.

Baik pengguna on-street parking untuk kendaraan R2 maupun R4 sama - sama didominasi oleh pengguna yang mempunyai maksud tujuan perjalanan untuk berbelanja dan kegiatan ini paling banyak dilakukan di area perdagangan dan jasa deret (K-3). 
c. Waktu/Lama Perjalanan

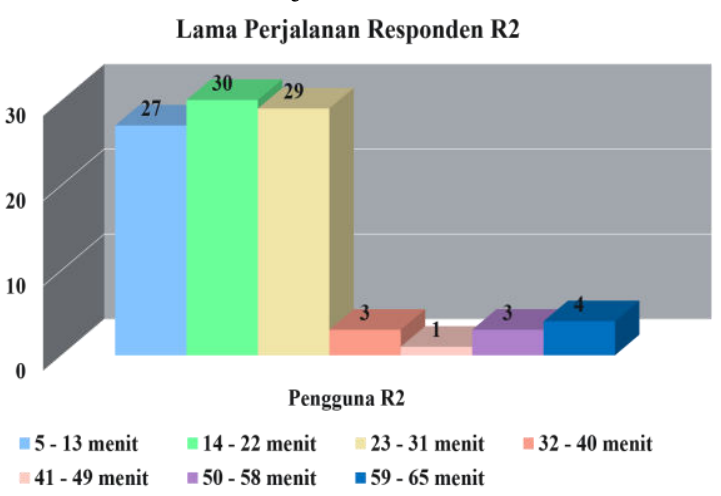

Gambar 8. Jumlah Pengguna Parkir R2 Berdasarkan Lama Perjalanan.

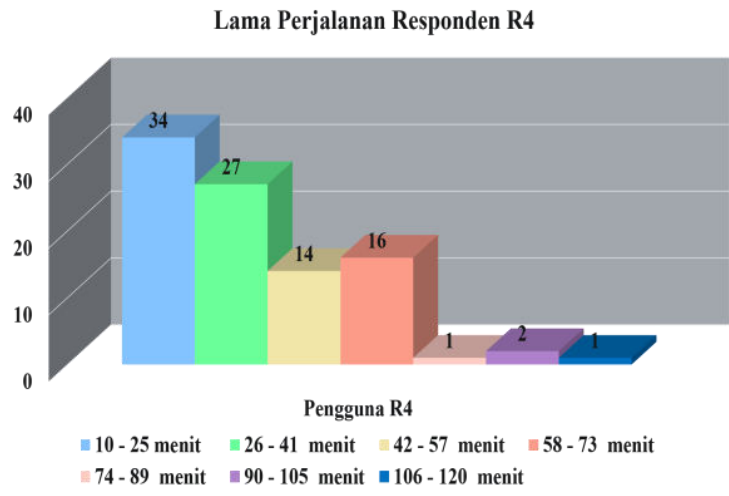

Gambar 9. Jumlah Pengguna Parkir R4 Berdasarkan Lama Perjalanan.

Dalam hal variabel lama perjalanan, untuk pengguna onstreet parking kendaraan R2 didominasi dengan responden yang memiliki lama perjalanan $14-22$ menit (31\% responden), sedangkan untuk kendaraan $\mathrm{R} 4$, sebanyak $36 \%$ responden membutuhkan waktu antara $10-25$ menit untuk mencapai kawasan Tunjungan dan Blauran.

d. Jumlah Tujuan Perjalanan

Jlh Tujuan Perjalanan Responden R2

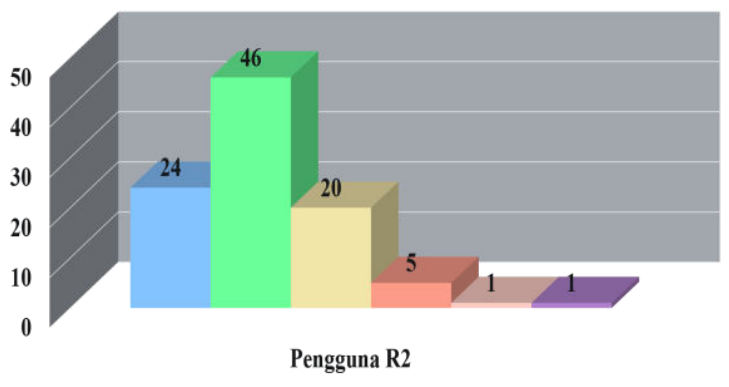

-1 tujuan $\quad 2$ tujuan $\square$ tujuan $₫ 4$ tujuan $\square$ tujuan $\quad 7$ tujuan

Gambar 10. Jumlah Pengguna Parkir R2 Berdasarkan Jumlah Tujuan Perjalanan.

Jumlah tujuan perjalanan yang dilakukan oleh pengguna onstreet parking yang membutuhkan biaya parkir setiap harinya untuk responden pengguna kendaraan R2 didomansi sebanyak 47\% yang mempunyai 2 tujuan perjalanan, begitu juga dengan pengguna fasilitas parkir untuk R4 didominasi oleh pengguna dengan 2 tujuan perjalanan ( $46 \%$ responden).

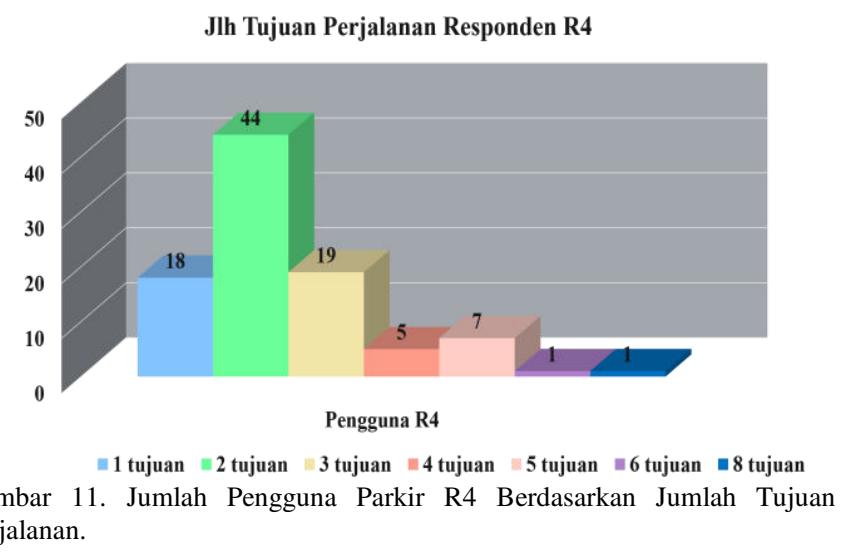

B. Identifikasi Karakteristik On-Street Parking di Kawasan Tunjungan dan Blauran Kota Surabaya

a. Durasi Parkir

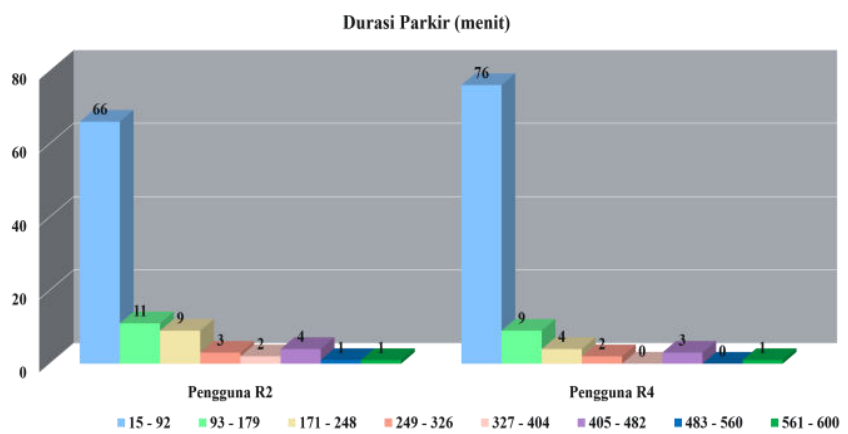

Gambar 12. Jumlah Pengguna Parkir Berdasarkan Durasi Parkir.

Baik pengguna parkir R2 maupun R4 pada fasilitas on-street parking Zona Tunjungan dan Blauran Kota Surabaya sama sama didominasi oleh responden yang mempunyai durasi parkir antara 15 - 92 menit. Untuk pengguna R2 yaitu sebanyak $68 \%$ responden, sedangkan untuk pengguna R4 ada sebanyak $80 \%$ dari total keseluruhan respondennya.

b. Biaya/ Tarif Parkir

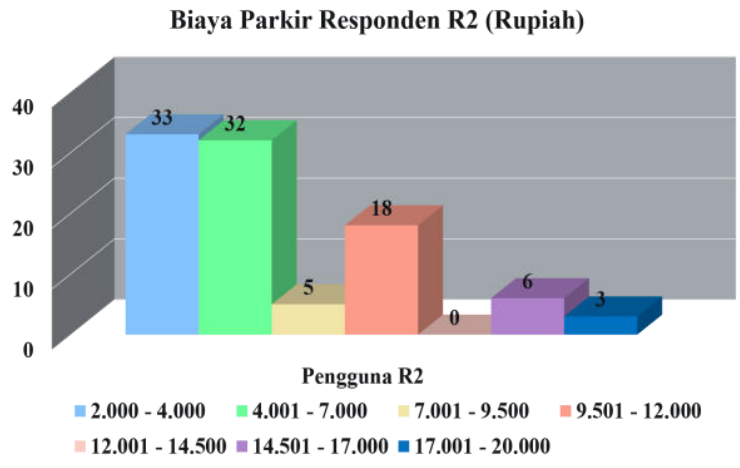

Gambar 13 Jumlah Pengguna Parkir R2 Berdasarkan Biaya Parkir.

Pengguna on-street parking kendaraan R2 di Zona Tunjungan dan Blauran Kota Surabaya didominasi dengan responden yang mengeluarkan biaya parkir antara Rp $2.000-$ Rp 4.500 per harinya (34\% responden). Untuk kendaraan R4 lebih di dominasi oleh pengguna yang mengeluarkan biaya parkir antara Rp 5.000 - Rp 11.000 per harinya (43\% responden). 


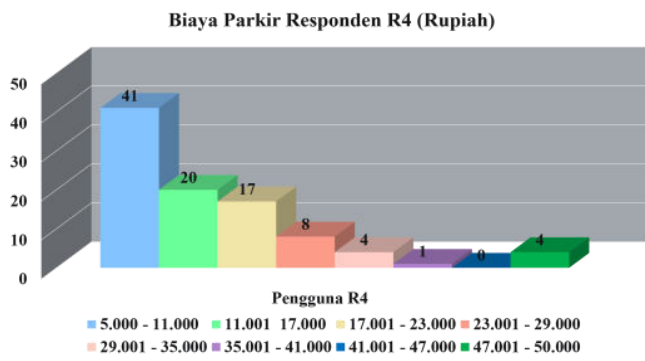

Gambar 14. Jumlah Pengguna Parkir R4 Berdasarkan Biaya Parkir.

\section{c. Jarak Berjalan Kaki}

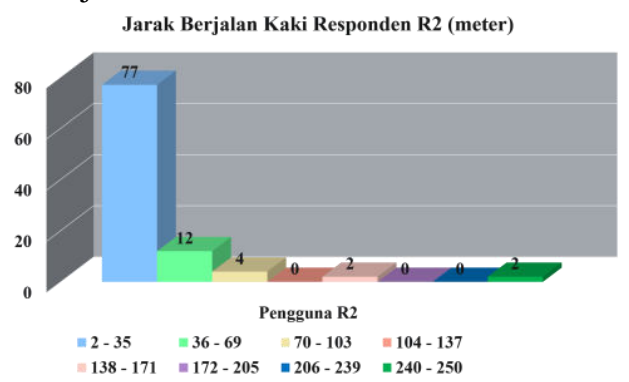

Gambar 15. Jumlah Pengguna Parkir R2 Berdasarkan Jarak Berjalan Kaki

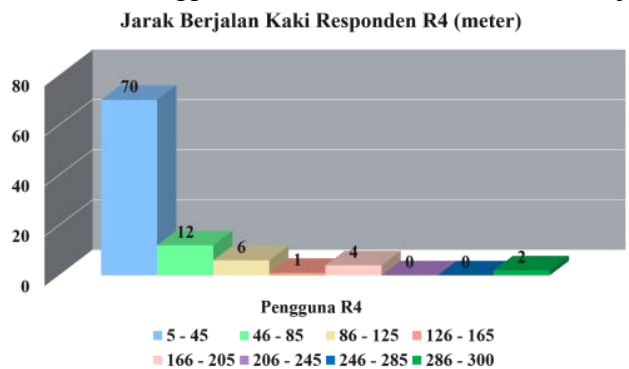

Gambar 16 Jumlah Pengguna Parkir R4 Berdasarkan Jarak Berjalan Kaki

Dalam variabel jarak berjalan kaki, untuk pengguna onstreet parking kendaraan R2 sebanyak 80\% respondennya memakirkan kendaraan mereka dengan jarak antara $2-35$ meter dari titik tujuan perjalanannya, sedangkan untuk pengguna kendaraan R4 didominasi sebanyak 74\% responden memarkirkan kendaraannya dengan jarak antara 5 - 45 meter.

d. Tingkat Kemudahan

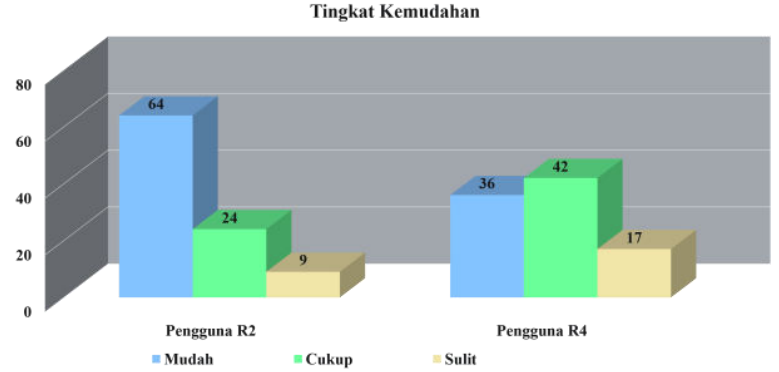

Gambar 17. Jumlah Pengguna Parkir Berdasarkan Tingkat Keamanan.

Pengguna on-street parking R2 lebih banyak yang memberikan penilaian "Mudah" terhadap tingkat kemudahan fasilitas parkirnya (66\% responden), sedangkan pengguna R4 lebih didominasi oleh penilaian "Cukup" (46\% responden). Tingkat kemudahan ini ditinjau dari informasi mengenai ketersediaan slot parkir, petunjuk dan penandaan/ signage di sekitar fasiltas parkir, serta kelancaran sirkulasi parkir.

e. Tingkat Keamanan
Penilaian tingkat keamanan ditinjau dari keberadaan kamera pengawas atau CCTV, mekanisme penjagaan dan pengawasan oleh juru parkir, serta ketersediaan fasilitas penerangan. Baik pengguna on-street parking bagi kendaraan R2 maupun R4 sama - sama didominasi oleh responden yang memberikan penilaian "Cukup".

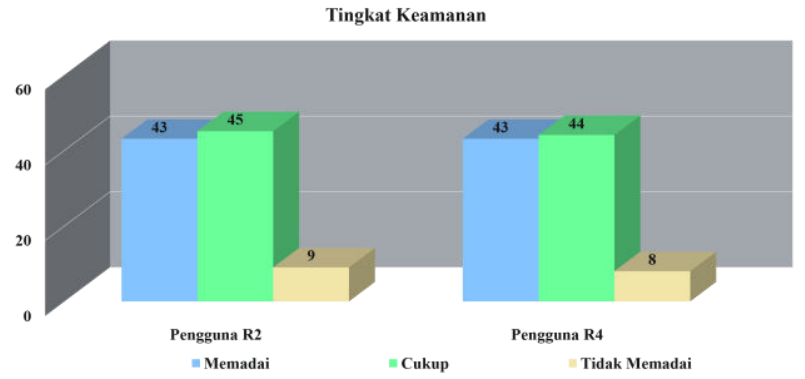

Gambar 18. Jumlah Pengguna Parkir Berdasarkan Tingkat Kemudahan.

C. Analisa Faktor - Faktor yang Memengaruhi Pemilihan On-Street Parking Kawasan Tunjungan dan Blauran Kota Surabaya

1. Pengguna Parkir Kendaraan Bermotor Roda Dua (R2)

Model faktor - faktor pemilihan on-street parking ini diolah berdasarkan variabel - variabel yang sudah diindentifikasi dari karakteristik pada sasaran sebelumnya dengan menggunakan analisa regresi logistik biner. Sebelum beralih pada model, terlebih dahulu dilakukan uji kesesuaian model untuk melihat kelayakan model. Berikut ini merupakan uji - uji model yang dilakukan.

Tabel 1.

Uji Statistik Regresi Logistik R2

\begin{tabular}{|c|c|c|}
\hline Uji S & Hipotesa & Keterangan \\
\hline $\begin{array}{l}\text { Estimasi } \\
\text { Parameter } \\
\text { (Iteration } \\
\text { History) }\end{array}$ & - & $\begin{array}{l}\text { Nilai -2 Log likelihood model sebesar } \\
\text { 131,142, kemudian dengan proses } 6 \text { kali } \\
\text { iterasi dihasilkan nilai -2 Log likelihood } \\
93,941 . \\
\text { Perbandingan nilai -2 Log likelihood yang } \\
\text { lebih kecil setelah iterasi, maka model } \\
\text { dianggap telah mendapat nilai likelihood } \\
\text { maksimal dan model dinyatakan fit. }\end{array}$ \\
\hline \multicolumn{3}{|c|}{ Kelayakan dan Kesesuaiaan Model (Goodness of Fit) } \\
\hline $\begin{array}{l}\text { Kelayakan } \\
\text { Model } \\
\text { (Hosmer and } \\
\text { Lemeshow } \\
\text { Test) }\end{array}$ & $\begin{array}{c}\text { square }> \\
0,1\end{array}$ & $\begin{array}{l}\text { Hasil uji kelayakan model sebesar } \mathrm{Sig}=0,870 \text {. } \\
\text { Karena nilai signifikansinya }>0,1 \text { maka hal ini } \\
\text { menunjukkan model yang terbentuk mampu } \\
\text { memprediksi nilai observasi dengan baik dan } \\
\text { cocok dengan nilai observasinya. }\end{array}$ \\
\hline $\begin{array}{l}\text { oefisien } \\
\text { eterminasi } \\
\text { Model } \\
\text { ummary) }\end{array}$ & - & $\begin{array}{l}\text { Nilai Nagelkerke } R \text { Square }=0,438 \text { artinya } \\
\text { besar variansi variabel dependen yang bisa } \\
\text { dijelaskan oleh variabel independen adalah } \\
43,8 \% \text {, sedangkan sisan } 56,2 \% \text { dipengaruhi } \\
\text { oleh faktor lain. }\end{array}$ \\
\hline $\begin{array}{l}\text { Tabel } \\
\text { Klasifikasi } \\
\text { (Classification } \\
\text { Table) }\end{array}$ & - & $\begin{array}{l}\text { Overall Percentage }=73,2 \text {. } \\
\text { Model ini mampu memprediksi dengan tingkat } \\
\text { keakuratan sebesar } 73,2 \% \text {, }\end{array}$ \\
\hline $\begin{array}{l}\text { engujian } \\
\text { ecara } \\
\text { eseluruhan } \\
\text { Dverall Test) }\end{array}$ & Sig $<0,1$ & $\begin{array}{l}\text { Sig. }=0,001 . \text { Maka secara keseluruhan dalam } \\
\text { model minimal ada satu variabel independen } \\
\text { yang berpengaruh kepada variabel dependen. }\end{array}$ \\
\hline
\end{tabular}

Sumber: Penulis, 2018

Adapun model yang dihasilkan telah dianggap memenuhi kriteria dalam uji model regresi logistik dipaparkan sebagai berikut. 
Tabel 2.

Hasil Model Regresi Logistik Biner Kendaraan R2 Variables in the Equation

\begin{tabular}{llrrrl}
\hline \multicolumn{5}{c}{ Variables in the Equation } \\
\hline & \multicolumn{1}{c}{ B } & \multicolumn{1}{c}{ Wald } & \multicolumn{1}{l}{ df } & Sig. \\
\hline St & Gender & .566 & .757 & 1 & .384 \\
ep & Usia & .025 & .787 & 1 & .375 \\
$1^{\mathrm{a}}$ & 1.234 & 10.394 & 1 & .001 \\
& Pendapatan & -.277 & .993 & 1 & .319 \\
& Jlh Kepemilikan Kendaraan & & 1.740 & 2 & .419 \\
& Maksud Perjalanan(Lainnya) & & 1.714 & 1 & .190 \\
Maksud Perjalanan(Bekerja) & -1.549 & .704 & .516 & 1 & .472 \\
Maksud Perjalanan(Berbelanja) & -.701 & .003 & 1 & .956 \\
Lama Perjalanan & .001 & .200 & .270 & 1 & .603 \\
Jlh Tujuan Perjalanan & -.008 & 4.610 & 1 & .032 \\
Durasi Parkir & -.000170 & 2.886 & 1 & .089 \\
Biaya Parkir & .005 & .487 & 1 & .485 \\
Jarak Berjalan Kaki & & 2.054 & 2 & .358 \\
T. Kemudahan(sulit) & 1.446 & 1.210 & 1 & .271 \\
T. Kemudahan(cukup) & .659 & .256 & 1 & .613 \\
T. Kemudahan(mudah) & & .609 & 2 & .737 \\
T. Keamanan(tidak memadai) & .682 & .591 & 1 & .442 \\
T. Keamanan(cukup) & .479 & .267 & 1 & .605 \\
T. Keamanan(memadai) & -2.777 & 1.489 & 1 & .222 \\
Constant & & & & \\
\hline \hline
\end{tabular}

Sumber: Hasil Analisis SPSS, 2018

Dari hasil analisis, ada 3 variabel independen yang secara signifikan memberikan pengaruh terhadap variabel dependen di dalam model. Keadaan ini dilihat dari signifikansi masing masing variabel independen tersebut lebih kecil dari 0,1 . Variabel independen yang secara bersama - sama memberikan pengaruh terhadap pemilihan on-street parking terdiri dari karakteristik perlaku parkir yaitu pendapatan $\left(\mathrm{X}_{3}\right)$, karakteristik perparkiran, yaitu durasi parkir $\left(\mathrm{X}_{8}\right)$ dan biaya parkir $\left(\mathrm{X}_{9}\right)$.

Tabel 3.

Variabel yang Memengaruhi Pemilihan On-Street Parking R2

\begin{tabular}{lrrrr}
\hline \hline \multicolumn{4}{c}{ Variables in the Equation } \\
\cline { 3 - 5 } & \multicolumn{1}{c}{$\mathrm{B}$} & \multicolumn{1}{c}{ Sig. } & \multicolumn{1}{c}{$\operatorname{Exp}(\mathrm{B})$} \\
\hline Pendapatan $\left(\mathrm{X}_{2}\right)$ & 1.234 & .001 & 3.435 \\
\hline Durasi Parkir $\left(\mathrm{X}_{8}\right)$ & -.008 & .032 & .992 \\
\hline Biaya Parkir $\left(\mathrm{X}_{9}\right)$ & -.000170 & .089 & 1.000 \\
\hline Constant & -2.777 & .222 & .062 \\
\hline \hline
\end{tabular}

Sumber: Hasil Analisis SPSS, 2018

Pada karakteristik pelaku parkir, yaitu variabel pendapatan $\left(\mathbf{X}_{\mathbf{3}}\right)$, diketahui bahwa kecenderungan pemilihan on-street parking seorang dengan tingkat pendapatan Rp 500.001 - Rp 1.500 .000 adalah 3,435 kalinya lebih tinggi dibandingkan dengan yang mempunyai tingkat pendapatan < $\mathrm{Rp}$ 500.000. Semakin tinggi tingkat pendapatan responden, maka responden cenderung semakin tidak responsif terhadap skenario atau artinya responden lebih banyak memilih tetap parkir ketika dihadapkan dengan skenario - skenario yang ada.

Dalam karaktersitik perparkiran, di varibel durasi parkir (X) didapatkan bahwa semakin panjang durasi parkir dengan kenaikan per satu menit, kecenderungan seseorang untuk menggunakan fasilitas on-street parking menurun menjadi 0,992 kalinya dibandingkan peluang tidak memilih on-street parking (tidak parkir di zona parkir, menggunakan transportasi publik, atau tidak melakukan perjalanan ke kawasan zona parkir). Artinya, semakin lama durasi parkir seseorang, maka kecenderungan pemilihan on-street parking dalam zona menjadi semakin rendah.
Sedangkan pada variabel biaya parkir $\left(\mathbf{X}_{\mathbf{9}}\right)$, setiap terjadi penambahan $\mathrm{Rp} 1$ pada total biaya parkir yang dikeluarkan dalam variabel ini, maka probabilitas seseorang untuk menggunakan fasilitas on-street parking pada kawasan Tunjungan dan Blauran adalah cenderung menjadi 1,000 kalinya. Semakin besar pengeluaran biaya parkir seorang responden, respon yang diberikan juga semakin responsif terhadap skenario yang ditawarkan dalam kuesioner.

Sehingga dapat disusun model yang menunjukkan probabilitas pemilihan on-street parking untuk kendaraan bermotor roda dua atau sepeda motor seperti berikut:

$$
\begin{gathered}
\ln \left[\frac{p}{1-p}\right]=-2,777+1,234 X_{2}-0.008 X_{8}-0,000170 X_{9} \\
p=\frac{1}{1+e^{-\left(-2,777+1,234 X_{2}-0.008 X_{8}-0,000170 X_{9}\right)}}
\end{gathered}
$$

Secara keseluruhan, variabel yang paling berpengaruh besar pada pemilihan on-street parking untuk jenis kendaraan sepeda motor adalah pendapatan dan biaya parkir.

2. Pengguna Parkir Kendaraan Bermotor Roda Empat (R4)

Data yang didapatkan dari indentifikasi karakteristik pada sasaran sebelumnya digunakan untuk membangun model pemilihan on-street parking kendaraan R4 menggunakan analisa regresi logistik biner. Terlebih dahulu dilakukan uji kesesuaian model untuk melihat kelayakan model. Berikut merupakan uji - uji model yang dilakukan.

Tabel 4.

\begin{tabular}{|c|c|c|}
\hline Uji Statistik & Hipotesa & Keterangan \\
\hline $\begin{array}{l}\text { Estimasi } \\
\text { Parameter } \\
\text { (Iteration } \\
\text { History) }\end{array}$ & - & $\begin{array}{l}\text { Tahap awal nilai -2 Log likelihood model } \\
\text { sebesar 109,503, kemudian dengan proses } \\
6 \text { kali iterasi dihasilkan nilai -2 Log } \\
\text { likelihood 90,505. } \\
\text { Perbandingan nilai -2 Log likelihood yang } \\
\text { lebih kecil setelah iterasi, maka model } \\
\text { dianggap telah mendapat nilai likelihood } \\
\text { maksimal dan model dinyatakan fit. }\end{array}$ \\
\hline \multicolumn{3}{|c|}{ Kelayakan dan Kesesuaiaan Model (Goodness of Fit) } \\
\hline $\begin{array}{l}\text { Kelayakan } \\
\text { Model } \\
\text { (Hosmer and } \\
\text { Lemeshow } \\
\text { Test) }\end{array}$ & $\begin{array}{c}\text { Chi- } \\
\text { square > } \\
0,1\end{array}$ & $\begin{array}{l}\text { Hasil uji kelayakan model sebesar Sig }= \\
0,884 \text {. Karena nilai signifikansinya }>0,1 \\
\text { maka hal ini menunjukkan model yang } \\
\text { terbentuk mampu memprediksi nilai } \\
\text { observasi dengan baik dan cocok dengan } \\
\text { nilai observasinya. }\end{array}$ \\
\hline $\begin{array}{l}\text { Koefisien } \\
\text { Determinasi } \\
\text { (Model } \\
\text { Summary) }\end{array}$ & - & $\begin{array}{l}\text { Nilai Nagelkerke } R \text { Square }=0,265 \text { artinya } \\
\text { besar variansi variabel dependen yang bisa } \\
\text { dijelaskan oleh variabel independen adalah } \\
26,5 \% \text {, sedangkan sisan } 73,5 \% \text { dipengaruhi } \\
\text { oleh faktor lain. }\end{array}$ \\
\hline $\begin{array}{l}\text { Tabel } \\
\text { Klasifikasi } \\
\text { (Classificatio } \\
\text { n Table) }\end{array}$ & - & $\begin{array}{l}\text { Overall Percentage }=77,9 . \\
\text { Model ini mampu memprediksi dengan } \\
\text { tingkat keakuratan sebesar } 77,9 \% \text {. }\end{array}$ \\
\hline $\begin{array}{l}\text { Pengujian } \\
\text { Secara } \\
\text { Keseluruhan } \\
\text { (Overall Test) } \\
\end{array}$ & Sig $<0,1$ & $\begin{array}{l}\text { Sig. }=0,026 . \text { Maka secara keseluruhan } \\
\text { dalam model minimal ada satu variabel } \\
\text { independen yang berpengaruh kepada } \\
\text { variabel dependen. }\end{array}$ \\
\hline
\end{tabular}

Uji Statistik Regresi Logistik R4

Sumber: Penulis, 2018

Adapun model yang dihasilkan telah dianggap memenuhi kriteria - kriteria dalam uji model regresi logistik dipaparkan sebagai berikut. 
Tabel 5.

Hasil Model Regresi Logistik Biner Kendaraan R4 Variables in the Equation

\begin{tabular}{ll|rr|rr|}
\hline \multicolumn{5}{c}{ Variables in the Equation } \\
\hline \multicolumn{1}{c}{ S Gender } & \multicolumn{1}{c}{ B } & \multicolumn{1}{c}{ Wald } & df & \multicolumn{1}{c}{ Sig. } \\
te Usia & .752 & 1.266 & 1 & .260 \\
$\mathrm{p}$ & Pendapatan & -.058 & 4.295 & 1 & .038 \\
1 Jlh Kendaraan & .005 & .000 & 1 & .992 \\
$\mathrm{a}$ & -.096 & .273 & 1 & .602 \\
Maksud Perjalanan(Lainnya) & & 6.574 & 2 & .037 \\
Maksud Perjalanan(Bekerja) & 2.330 & 4.091 & 1 & .043 \\
Maksud Perjalanan(Berbelanja) & .090 & .009 & 1 & .923 \\
Lama Perjalanan & -.005 & .106 & 1 & .744 \\
Jlh Tujuan Perjalanan & -.035 & .010 & 1 & .920 \\
Durasi Parkir & -.012 & 3.073 & 1 & .080 \\
Biaya Parkir & .000 & .033 & 1 & .857 \\
Jarak Berjalan Kaki & .014 & 6.158 & 1 & .013 \\
T. Kemudahan(sulit) & & 2.207 & 2 & .332 \\
T. Kemudahan(cukup) & -.047 & .003 & 1 & .959 \\
T. Kemudahan(mudah) & .900 & 1.154 & 1 & .283 \\
T. Keamanan(tidak memadai) & & .074 & 2 & .963 \\
T. Keamanan(cukup) & .330 & .074 & 1 & .786 \\
T. Keamanan(memadai) & .316 & .064 & 1 & .800 \\
Constant & .679 & .100 & 1 & .752 \\
\hline \hline
\end{tabular}

Sumber: Hasil Analisis SPSS, 2018

Variabel - varibel independen akan berpengaruh signifikan secara parsial terhadap variabel dependen jika nilai signfikansinya $<0,1$. Maka, yang memberikan pengaruh terhadap pemilihan on-street parking kendaraan mobil terdiri dari karakteristik pelaku parkir, yaitu variabel usia $\left(\mathrm{X}_{2}\right)$, karaktersitik perjalanan pelaku parkir, yaitu variabel maksud perjalanan $\left(\mathrm{X}_{5}\right)$, karakteristik perparkiran, yaitu durasi parkir $\left(\mathrm{X}_{8}\right)$ dan jarak berjalan kaki $\left(\mathrm{X}_{10}\right)$.

Tabel 6.

Variabel yang Memengaruhi Pemilihan On-Street Parking R4 Variables in the Equation

\begin{tabular}{lcr|r}
\hline \multicolumn{4}{c}{ Variables in the Equation } \\
\cline { 2 - 4 } & \multicolumn{1}{c}{$\mathrm{B}$} & \multicolumn{1}{c}{ Sig. } & \multicolumn{1}{c}{$\operatorname{Exp}(\mathrm{B})$} \\
Usia $\left(\mathrm{X}_{2}\right)$ & -.058 & .038 & .943 \\
Maksud Perjalanan(Lainnya) $\left(\mathrm{X}_{5 \mathrm{a}}\right)$ & & .037 & \\
Maksud Perjalanan(Bekerja) $\left(\mathrm{X}_{5 \mathrm{~b}}\right)$ & 2.330 & .043 & 1.276 \\
Maksud Perjalanan(Berbelanja) $\left(\mathrm{X}_{5 \mathrm{c}}\right)$ & .090 & .923 & 1.094 \\
Durasi Parkir $\left(\mathrm{X}_{8}\right)$ & -.012 & .080 & .988 \\
Jarak Berjalan Kaki $\left(\mathrm{X}_{10}\right)$ & .014 & .013 & 1.014 \\
Constant & .679 & .752 & 1.973 \\
\hline \hline Sumber: Hasil Analisis SPSS, 2018 & & &
\end{tabular}

Dalam karakteristik pelaku parkir, yaitu varibel usia $\left(\mathbf{X}_{2}\right)$, setiap penambahan satu tahun dalam variabel usia, maka peluang pemilihan on-street parking akan menjadi 0,943 kalinya. Semakin tua umur seseorang, maka kecenderungannya untuk memilih on-street parking dalam zona akan semakin menurun.

Kemudian dalam karakteristik perjalanan pelaku parkir, ypada variabel maksud perjalanan $\left(\mathbf{X}_{5}\right)$, kecenderungan pemilihan on-street parking untuk maksud perjalanan bekerja adalah 1,276 kali lebih tinggi dari pada maksud perjalanan kategori "lainnya". Sedangkan kecenderungan pemilihan onstreet parking dengan maksud perjalanan berbelanja adalah 1,094 kali lebih tinggi dari pada maksud perjalanan kategori "lainnya", maka seseorang dengan maksud perjalan bekerja atau berbelanja akan cenderung lebih memilih on-street parking dari pada maksud perjalanan kategori "lainnya".

Pada karakteristik perparkiran, yaitu di variabel durasi parkir $\left(\mathbf{X}_{\mathbf{8}}\right)$, diketahui bahwa setiap penambahan atau kenaikan satu menit dalam durasi parkir, kecenderungan seseorang untuk menggunakan fasilitas on-street parking menurun menjadi 0,988 kalinya. Semakin panjang durasi parkir seseorang, probabilitasnya untuk melakukan atau memilih on-street parking dalam zona akan semakin kecil.

Sedangkan untuk variabel jarak berjalan kaki $\left(\mathbf{X}_{10}\right)$, hasil dari model menunjukkan dengan setiap penambahan satu meter dalam jarak berjalan kaki dari fasilitas parkir ke tujuan akhir perjalanan, akan meningkatkan peluang pemilihan onstreet parking 1,014 kalinya dibandingkan dengan peluang tidak memilih on-street parking.

Sehingga dapat disusun model yang menunjukkan probabilitas pemilihan on-street parking untuk kendaraan bermotor roda empat atau mobil sebagai berikut:

$\ln \left[\frac{p}{1-p}\right]=0,679-0,058 X_{2}+2,330 X_{5 b}+0,090 X_{5 c}-0,012 X_{8}+0,014 X_{10}$ $p=\frac{1}{1+e^{-\left(0,679-0,058 X_{2}+2,330 X_{5 b}+0,090 X_{5 c}-0,012 X_{8}+0,014 X_{10}\right)}}$

Secara garis besar, adapun faktor - faktor yang memberikan pengaruh paling besar dalam pemilihan on-street parking untuk kendaraan R4 atau mobil adalah maksud perjalanan dan jarak berjalan kaki.

\section{KESIMPULAN}

Dari hasil pembahasan yang telah dilakukan, maka dapat disimpulkan beberapa hal sebagai berikut:

1. Berdasarkan karaktersitik pelaku parkir, untuk jenis kelamin baik pengguna parkir kendaraan bermotor R2 maupun R4 mempunyai karaktersitik yang sama didominasi oleh laki - laki. Di variabel usia, pengguna parkir dari kedua moda juga sama - sama didominasi oleh usia produktif. Pada varibel tingkat pendapatan, pengguna parkir R2 mempunyai dominasi tingkat pendapatan lebih rendah dari pada pengguna parkir R4, dan untuk variabel kepemilikan kendaraan, pengguna parkir R4 mempunyai rata - rata jumlah kepemilikan kendaraan yang lebih tinggi dari pada pengguna parkir R2.

2. Dalam karakteristik perjalanan pelaku parkrinya, di variabel tujuan baik pengguna parkir kendaraan R2 maupun R4 didominasi oleh tujuan perjalanan berbelanja. Pada variabel lama perjalanan, pengguna parkir kendaraan R2 mempunyai lama perjalanan yang lebih panjang dari pada pengguna kendaraan R4. Sedangkan untuk variabel jumlah tujuan perjalanan, kedua jenis pengguna fasilitas parkir ini mempunyai rata - rata jumlah perjalanan yang hampir sama;

3. Karaktersitik perparkirkan yang dinilai dari variabel durasi parkir, kedua kategori pengguna fasilitas on-street parking ini mempunyai dominasi durasi parkir yang cukup sama, untuk variabel biaya parkir pengguna parkir kendaraan R2 mempunyai rata - rata biaya parkir yang lebih rendah dari pada. Selanjutnya, dalam variabel jarak berjalan kaki, dalam kedua kategori pengguna parkir mempunyai rata - rata jarak berjalan kaki yang tidak jauh berbeda. Untuk tingkat kemudahan pengguna parkir kendaraan R2 lebih banyak yang memberikan nilai "mudah", sedangkan R4 lebih banyak memberikan nilai "cukup". Pengguna parkir kendaraan R2 dan R4 sama - 
sama didominasi penilaian "cukup" untuk tingkat keamanan parkir;

4. Pada pengguna parkir kendaraan R2, adapun faktor faktor yang memengaruhi pemilihan on-street parking nya di Kawasan Tunjungan dan Blauran Kota Surabaya pendapatan, variabel durasi parkir, dan biaya parkir dengan model sebagai berikut

$$
p=\frac{1}{1+e^{-\left(-2,777+1,234 X_{2}-0.008 X_{8}-0,000170 X_{9}\right)}}
$$

Variabel yang paling berpengaruh dalam pemilihan onstreet parking untuk kendaraan R2 adalah tingkat pendapatan dan biaya parkir, dimana setiap perubahan 1 satuan tingkat pendapatan seseorang, maka probabilitas pemilihan on-street parking akan meningkat menjadi 3,435 kalinya dibandingkan dengan peluang tidak memilih on-street parking (tidak parkir di zona, menggunakan transportasi publik, atau tidak melakukan perjalanan ke kawasan zona parkir), sedangkan setiap peningkatan Rp 1 dalam biaya parkir probabilitas pemilihan parkir menjadi 1,000 kalinya;

5. Sedangkan untuk pengguna parkir kendaraan R4, faktor faktor yang memengaruhi pemilihan on-street parking nya adalah usia, maksud perjalanan, durasi parkir, dan jarak berjalan kaki dengan model yang dihasilkan dari analisis regresi logistik yaitu:

$$
p=\frac{1}{1+e^{-\left(0,679-0,058 X_{2}+2,330 X_{5 b}+0,090 X_{5 c}-0,012 X_{8}+0,014 X_{10}\right)}}
$$

Untuk kendaraan R4 atau mobil, variabel yang paling memiliki pengaruh paling besar dalam maksud perjalanan, dimana bila seseorang mempunyai maksud perjalanan untuk bekerja maka probabilitas pemilihan on-street parking meningkat menjadi 1,276 kalinya dibandingkan dengan peluang tidak memilih on-street parking (tidak parkir di zona, menggunakan transportasi publik, tidak melakukan perjalanan ke kawasan zona parkir).

\section{DAFTAR PUSTAKA}

[1] P. Barter, "On - Street Parking Management," 2016.

[2] Pemerintah Kota Surabaya, "Peraturan Wali Kota Surabaya Nomor 3 Tahun 2017 tentang Pedoman Penetapan Parkir Zona di Kota Surabaya," Surabaya, 2017.

[3] T. Rye, "Manajemen Parkir: Sebuah Kontribusi menuju Kota yang Layak Huni," 2011.

[4] O. Z. Tamin, Perencanaan dan Pemodelan Transportasi, 2nd ed. Bandung: Institut Teknologi Bandung, 2000.

[5] Dinas Perhubungan Kota Surabaya, "Surat Keputusan (SK) Kepala Dinas Perhubungan (Kadishub) Kota Surabaya Nomor 188.45/5491/436.7.14/2017," Surabaya, 2017.

[6] T. Litman, "Parking Management Strategies, Evaluation, and Planning," 2016.

[7] X. Ma, X. Sun, Y. He, and Y. Chen, "Parking choice behavior investigation: A case study at Beijing Lama Temple," Procedia Soc. Behav. Sci., vol. 96, pp. 2635 - 2642, 2013.

[8] K. Teknomo and K. Hakao, "Parking behavior in central business district a study case of Surabaya Indonesia," EASTS J., vol. 2, no. 2, pp. $551-570,1997$.

[9] H. J. Griffioen-Young, H. J. W. Jassen, D. J. C. V. Amelsfoort, and J. J. Langefeld, "The Psychology of Parking," in Proceedings of the ECOMM 2004 Conference, 2004.

[10] E. Stephanie, Slovin Formula Sampling Techniques. USA: Houghton-Mifflin, 2003.

[11] T. Heather, "Stated preference survey design and pre-test for valuing influence factors for bicycle use," Institute Transportation Technis che Universität München, 2011. 